\title{
STUDI TENTANG PERKEMBANGAN INDUSTRI PENERBIT BUKU SEKOLAH SETELAH TERBITNYA BUKU SEKOLAH ELEKTRONIK
}

\author{
Benget Simamora, Sentot Mardjuki, Frans Parera, dan Irene Maria Juli Astuti \\ Program Studi Penerbitan, Politeknik Negeri Media Kreatif \\ Simamorabenget@gmail.com \\ Sentot.mardjuki@polimedia.ac.id \\ Frans.parera@polimedia.ac.id \\ Irene.maria562@gmail.com
}

\begin{abstract}
Abstrak
Perkembangan penerbit buku pelajaran tiga tahun setelah terbitnya BSE dan tiga tahun sebelumnya telah mengalami perubahan yang signifikan. Ada empat variabel yang dikembangkan menjadi indikator instrumen yaitu, variabel persentasi buku teks pelajaran dengan indikator produksi buku teks pelajaran, faktor-faktor yang memengaruhi perubahan buku teks pelajarandengan indikator yang memengaruhi harga buku pelajaran. Metode yang digunakan dalam penelitian ini adalah kualitatif deskriptif, namun pendekatan kuantitatif juga dilakukan untuk memperkuat data kualitatif. Sampel penelitian diambil dari populasi penerbit buku sekolah yang ada di wilayah Jabodetabek, Bandung, dan Jateng. Teknik pengambilan data dengan cara menyebarkan kuesioner dan wawancara langsung. Analisis data dengan cara penghitungan persentase untuk data kuantitatif dan pengolahan hasil wawancara untuk data kualitatif. Tujuan penelitian ini adalah untuk memberikan solusi karena dampak kebijakan BSE tersebut dan usulan kebijakan kepada pemerintah mengenai pengadaan buku pelajaran secara nasional. Kebijakan pembelian hak cipta tidak konsisten, berubah-ubah yang mengakibatkan kualitas buku semakin rendah. Efek dominonya penerbit-penerbit skala menengah ke bawah mengalami penurunan produksi secara drastis dan penerbit menengah ke atas memperoleh pemesanan yang signifikan dengan keuntungan sangat kecil. Penerbit menengah ke atas yang masih bertahan memproduksi BSE, bukan untuk mencari profit yang signifikan, melainkan untuk mempertahankan pelanggan mereka selama ini karena produk BSE yang dipesan dijadikan satu paket dengan buku pengayaan. Kebijakan BSE telah mengubah kebijakan bisnis penerbitan buku sekolah.
\end{abstract}

Kata kunci: BSE, penerbit buku sekolah, kebijakan perbukuan nasional

\section{PENDAHULUAN}

Kebijakan Kementerian

Pendidikan Nasional untuk membeli hak cipta buku-buku teks pelajaran dimaksudkan untuk menyediakan buku yang bisa diunduh melalui 
jaringan internet yang dikenal sebagai Buku Sekolah Elektronik (BSE). Pemerintah membebaskan siapa saja untuk menggandakan buku-buku tersebut sepanjang harga jualnya tidak melebihi harga eceran tertinggi (HET), yang ditetapkan oleh pemerintah, serta Peraturan Menteri Pendidikan Nasional yang melarang sekolah untuk membeli buku apapun dari penerbit kecuali buku teks pelajaran yang hak ciptanya berasal dari pemerintah. Kebijakan itu tentu sangat menggembirakan karena berpihak pada masyarakat secara luas.

Namun, keputusan itu merupakan pukulan besar bagi para penerbit buku sekolah. Pasar bagi buku sekolah yang bukan elektronik menjadi tertutup. Oleh karena itu, banyak penerbit buku sekolah yang terpaksa mengurangi kegiatannya, dan pada gilirannya mengurangi karyawannya. Jika semua penerbit buku sekolah beralih ke buku non sekolah maka siapa lagi yang bisa melakukan inovasi untuk mendorong dan membimbing para guru untuk menulis dan menerbitkan buku yang baik. Industri penerbitan buku adalah sebuah industri yang faktor idealismenya jauh lebih besar dari faktor komersilnya. Para usahawan besar yang tidak memiliki tradisi dan keahlian sebagai penerbit, belum tentu mau dan bisa melakukan inovasi sebagaimana yang selama ini telah dilakukan oleh penerbit buku sekolah.

Beberapa penerbit buku sekolah masih bisa bertahan dengan memproduksi buku teks pelajaran non-BSE untuk kebutuhan sekolah swasta sebagai pendamping BSE atau pengganti BSE. Upaya lain yang dilakukan oleh penerbit buku sekolah adalah dengan memproduksi buku pengayaan BSE dengan menggantungkan distribusi melalui agen dan saluran toko buku.

Kehadiran BSE dinilai belum relevan diluncurkan dalam konteks keindonesiaan yang hingga kini masih kesulitan dalam jaringan internet. Selain masih terbilang mahal, internet di negeri ini belum memiliki jaringan infrastruktur yang merata. Akibatnya, BSE yang menjadi ikon buku murah untuk rakyat justru lebih terkesan mahal dan inklusif daripada buku teks versi cetak. Hanya mereka yang memiliki koneksi internet yang sebagian besar 
tinggal di perkotaan yang bisa mengaksesnya. Rakyat miskin yang sebagian besar tinggal di pedesaan yang seharusnya menjadi sasaran BSE justru hanya bisa menjadi penonton dari balik layar (REXIKAPI Editor's, 2009).

Adapun tujuan penelitian adalah sebagai berikut.

1. untuk mengetahui berapa persentase perubahan produksi buku teks pelajaran oleh penerbit buku sekolah;

2. untuk mengetahui faktor-faktor yang berpengaruh terhadap persentase perubahan produksi buku teks pelajaran oleh penerbit buku sekolah;

3. untuk memberikan solusi agar dapat mengatasi dampak BSE;

4. untuk memberikan usulan kebijakan pemerintah sehubungan dengan dampak BSE.

\section{METODE PENELITIAN}

Penelitian ini menggunakan metode kualitatif deskriptif. Namun demikian pendekatan kuantitatif juga dilakukan agar diperoleh gambaran hasil kajian yang lebih lengkap dan lebih kuat. Penelitian deskriptif kualitatif adalah penelitian
Kebijakan BSE tersebut tentu memengaruhi produksi buku teks oleh penerbit buku sekolah. Seandainya perubahan itu sangat signifikan maka perlu diupayakan solusi dan kebijakan perbukuan nasional yang lebih kondusif.

untuk menemukan pengetahuan seluas-luasnya terhadap obyek penelitian pada suatu saat tertentu. Penelitian ini dimaksudkan untuk mengumpulkan informasi mengenai status suatu variabel atau tema, gejala atau keadaan yang ada, yaitu keadaan gejala menurut apa adanya pada saat penelitian dilakukan.

\section{HASIL DAN PEMBAHASAN}

Hasil penelitian ini mengacu pada tujuan penelitian yang ada dengan mengambil data sesuai instrumen yang ada. Data penelitian merupakan data kuantitatif berupa hasil kuesioner dan data kualitatif berupa hasil wawancara. Agar hasil wawancara dapat dirumuskan lebih otentik, perlu dilihat data kuantitatif sebagai data pendukung.

\section{Produksi Buku Sekolah pada \\ Penerbit Buku Sekolah Sebelum}




\section{dan Sesudah Adanya Kebijakan BSE}

Aspek produksi dalam sebuah penerbitan buku sekolah yang diteliti meliputi jenis-jenis buku, jumlah judul buku, dan jumlah eksemplar buku. Dari data kuantitatif diperoleh data sebagai berikut.

Tabel 1: Data Kuantitatif Hasil Penelitian Aspek Produksi

\section{Persentase}

Jenis Buku

\begin{tabular}{ccccc} 
& Persentase & \\
& & & \\
3 thn & 3 thn & & Perubahan \\
sblm & sth & & $(\%)$ \\
BSE & BSE & & \\
& & & \\
\hline 2 & 8 & $37,5 \%$ & $(+)$ \\
\hline 9 & 5 & 25 & $(-)$ \\
\hline 9 & 4 & 31,25 & $(-)$ \\
\hline 5 & 9 & 25 & $(+)$ \\
\hline 2 & 9 & 43,75 & $(+)$ \\
\hline 16 & 16 & 0 & \\
\hline 16 & 16 & 0 & \\
\hline 16 & 16 & 0 & \\
\hline 16 & 16 & 0 & \\
\hline 5 & 5 & 0 & \\
\hline
\end{tabular}

\begin{tabular}{|c|c|c|c|c|}
\hline \multirow{4}{*}{$\begin{array}{l}\text { Jenjang } \\
\text { Pendidikan }\end{array}$} & SD & 9 & 5 & $25 \quad(-)$ \\
\hline & SMP & 9 & 4 & $31,25 \quad(-)$ \\
\hline & SMA & 5 & 9 & $25 \quad(+)$ \\
\hline & SMK & 2 & 9 & $43,75 \quad(+)$ \\
\hline \multirow{5}{*}{$\begin{array}{l}\text { Bidang } \\
\text { Ilmu }\end{array}$} & MIPA & 16 & 16 & 0 \\
\hline & Bahasa & 16 & 16 & 0 \\
\hline & IPS & 16 & 16 & 0 \\
\hline & PKn & 16 & 16 & 0 \\
\hline & Lain-Lain & 5 & 5 & 0 \\
\hline \multicolumn{2}{|c|}{ Jumlah Judul } & $\begin{array}{c}3 \text { thn sblm } \\
\text { BSE } \\
\text { (jmlh pnb) }\end{array}$ & $\begin{array}{c}3 \text { thn stlh BSE } \\
\text { (jmlh pnb) }\end{array}$ & $\begin{array}{c}\text { Perubahan } \\
(\%)\end{array}$ \\
\hline \multicolumn{2}{|l|}{$<=12$} & 2 & 7 & $31,25 \quad(+)$ \\
\hline \multicolumn{2}{|l|}{$12-60$} & 3 & 5 & $12,5 \quad(+)$ \\
\hline \multicolumn{2}{|l|}{$60-100$} & 1 & 0 & $6,25 \quad(-)$ \\
\hline \multicolumn{2}{|l|}{$100-200$} & 5 & 2 & $18,75 \quad(-)$ \\
\hline \multicolumn{2}{|l|}{$>=200$} & 5 & 2 & $18,75 \quad(-)$ \\
\hline
\end{tabular}




\begin{tabular}{|c|c|c|c|c|}
\hline \multicolumn{2}{|c|}{ Jumlah Eksemplar } & \multirow{2}{*}{$\begin{array}{c}\text { Tiga Tahun } \\
\text { Sblm BSE } \\
2\end{array}$} & \multirow{2}{*}{$\begin{array}{c}\text { Tiga Tahun } \\
\text { Ssdh BSE } \\
16\end{array}$} & $\begin{array}{c}\text { Perubahan } \\
(\%)\end{array}$ \\
\hline \multirow[t]{5}{*}{ TK } & $<=50.000$ & & & 87,5 \\
\hline & $50.000-100.000$ & - & - & \\
\hline & $100.000-300.000$ & - & - & \\
\hline & $300.000-500.000$ & - & - & \\
\hline & $>=500.000$ & - & - & \\
\hline \multirow[t]{5}{*}{ SD } & $<=50.000$ & 2 & 8 & $37,5 \quad(+)$ \\
\hline & $50.000-100.000$ & 10 & 5 & $31.25 \quad(-)$ \\
\hline & $100.000-300.000$ & 4 & 1 & $18,75 \quad(-)$ \\
\hline & $300.000-500.000$ & 1 & 1 & 0 \\
\hline & $>=500.000$ & 1 & 1 & 0 \\
\hline \multirow[t]{5}{*}{ SMP } & $<=50.000$ & 5 & 10 & $31,25 \quad(+)$ \\
\hline & $50.000-100.000$ & 8 & 3 & $31,25 \quad(-)$ \\
\hline & $100.000-300.000$ & 2 & 2 & 0 \\
\hline & $300.000-500.000$ & 1 & 1 & 0 \\
\hline & $>=500.000$ & - & - & \\
\hline \multirow[t]{5}{*}{ SMA } & $<=50.000$ & 0 & 7 & $43,75 \quad(+)$ \\
\hline & $50.000-100.000$ & 2 & 5 & $18,75 \quad(+)$ \\
\hline & $100.000-300.000$ & 2 & 2 & 0 \\
\hline & $300.000-500.000$ & - & - & 0 \\
\hline & $>=500.000$ & 1 & 2 & $6,25 \quad(+)$ \\
\hline \multirow[t]{5}{*}{ SMK } & $<=50.000$ & 0 & 3 & $18,75 \quad(+)$ \\
\hline & $50.000-100.000$ & 2 & 3 & $6,25 \quad(+)$ \\
\hline & $100.000-300.000$ & 0 & 7 & $43,75 \quad(+)$ \\
\hline & $300.000-500.000$ & 1 & 2 & $6,25 \quad(+)$ \\
\hline & $>=500.000$ & 0 & 1 & $6,25 \quad(+)$ \\
\hline
\end{tabular}

\begin{tabular}{crrl}
\hline Data & hasil & penelitian & SMP sebesar 31,25\% pada kisaran \\
menunjukkan & bahwa & terjadi & $50.000-100.000$. Namun, terjadi \\
penurunan produksi pada buku SD & peningkatan produksi pada buku TK \\
sebesar $31,25 \% \quad$ pada kisaran & sebesar $87,5 \%$ pada kisaran $<=50 \%$ \\
$50.000-100.000$ eksemplar dan & eksemplar, SMA 43,75\% pada
\end{tabular}


kisaran $<=50.000$ dan SMK terjadi peningkatan di semua kisaran eksemplar yang ada. Jumlah judul pun menurun. Hal itu terlihat dari persentase penerbit yang kebanyakan menerbitkan judul buku pada kisaran $<=12$ judul per tahun dan $12-60$ judul per tahun, padahal tadinya 100 -200 dan $>=200$ judul per tahun.

Aspek produksi buku sekolah selalu terkait dengan kualitas yang sudah ditentukan oleh pemerintah melalui Badan Nasional Standar Pendidikan (BNSP). Penerbit yang akan memproduksi buku sekolah dan mengedarkannya harus menilaikan buku-buku tersebut pada proyek penilaian buku sekolah yang diselenggarakan oleh pemerintah.

Data hasil penelitian menunjukkan bahwa 100\% penerbit menjawab mengikuti program penilaian buku teks pelajaran yang diadakan oleh pemerintah. Namun tidak semua penerbit menerbitkan buku teks yang telah dinyatakan lulus oleh pemerintah mengingat peraturan tata niaga buku teks pelajaran yang memberatkan penerbit. Dengan berlakunya UU No 2 tahun 2008, penerbit tidak boleh berjualan langsung ke sekolah, menyulitkan penerbit dalam menyampaikan secara langsung keunggulan-keunggulan buku yang diterbitkan. Hal itu sebenarnya juga menyulitkan sekolah dalam pengadaan buku yang biasanya sudah didatangi penerbit, sekarang sekolah harus mencari informasi sendiri ke mana mereka harus mengadakan buku untuk peserta didik. Akibatnya, daerah-daerah yang tidak terjangkau dengan kemudahan informasi akan kesulitan membeli buku. Dampak yang lebih parah lagi, pembelajaran di sekolah tidak menggunakan buku teks pelajaran.

Ketersediaan buku di sekolah yang sangat minim itu juga diperparah dengan propaganda pemerintah yang mendengungdengungkan pendidikan gratis untuk masyarakat. Akibatnya, orang tua murid tidak mau membeli buku karena mereka beranggapan bahwa buku sudah disediakan gratis oleh pemerintah. Akibat yang lebih parah lagi, buku sebagai salah satu sumber belajar di sekolah sangat minim ketersediaannya. Hal itu sangat memengaruhi kualitas pembelajaran di sekolah. 
Mengingat betapa rumitnya peraturan tata niaga buku tersebut, penerbit mencari jalan keluar dengan menerbitkan buku-buku yang tidak terlalu diatur oleh pemerintah. Beberapa penerbit menerbitkan buku-buku teks yang memang belum dinilai oleh pemerintah. Ada $75 \%$ penerbit yang melakukan hal itu. Bahkan, sebagian penerbit (20\%) menerbitkan buku yang sudah dinyatakan tidak lulus oleh pemerintah mengingat kebutuhan sekolah yang masih menganggap buku tersebut bagus dan cocok untuk pembelajaran di kelas.

Ada catatan kecil yang perlu diketahui pada proses penilaian buku ini adalah adanya beberapa penerbit (40\%) yang mengalami proses penilaian buku dengan menggunakan faktor X. Artinya, buku itu bisa lulus karena adanya faktor X. Biasanya, karena penerbit ingin bukunya lulus, maka bila ada tawaran dari oknum, maka penerbit akan menyetujui dengan konsekuensi-konsekuensi biaya tertentu. Melihat praktek tersebut, tentunya kita patut mempertanyakan kualitas buku-buku yang dinyatakan lulus oleh pemerintah. Apakah semua buku- buku tersebut lulus murni karena memenuhi kualitas?

Penilaian buku untuk memenuhi kebutuhan BSE berlangsung dari tahun ke tahun, sejak tahun 2008 hingga tahun 2010. Buku-buku yang sudah lulus penilaian dibeli hak ciptanya oleh pemerintah dengan kisaran harga 100 juta rupiah per buku. Kemudian buku-buku tersebut di-up load di situs pusat perbukuan. Namun, dalam perjalanan waktu, sejak tahun 2009, pembelian hak cipta bukubuku untuk BSE yang lulus penilaian dilakukan dengan cara tender. Hal itu menyebabkan jatuhnya harga hak cipta sebuah buku yang tadinya 100 juta, ternyata ada penulis yang rela melepaskan hak ciptanya dengan harga yang jauh lebih murah dari 100 juta.

Tentu saja, fenomena itu menyebabkan tidak bergairahnya para penulis untuk menghasilkan buku-buku yang dinilaian ke proyek pemerintah. Ditambah lagi, ada beberapa penerbit yang bukubukunya sudah lulus penilaian tetapi tidak dimuat (up load) di internet oleh pemerintah. Hal itu tentu saja merugikan pihak penulis/penerbit 
yang berharap hasil karyanya bisa digunakan oleh masyarakat.

Selain kualitas, produksi buku teks pelajaran juga terkait dengan oplah penjualan buku. Penelitan ini mengumpulkan data oplah penjualan buku tiga tahun sebelum kebijakan BSE dan tiga tahun setelah kebijakan BSE.

Tabel 2: Data Penjualan Buku Teks yang Diterbitkan

\begin{tabular}{|c|c|c|c|c|}
\hline \multicolumn{2}{|c|}{ Jumlah Eksemplar } & \multirow{2}{*}{$\begin{array}{c}\text { 3 Thn } \\
\text { Sebelum } \\
\text { BSE } \\
2\end{array}$} & \multirow{2}{*}{$\begin{array}{c}\begin{array}{c}\text { 3 Thn } \\
\text { Sesudah } \\
\text { BSE }\end{array} \\
16\end{array}$} & \multirow{2}{*}{$\begin{array}{c}\text { Perubahan } \\
(\%)\end{array}$} \\
\hline \multirow[t]{5}{*}{ TK } & $<=50.000$ & & & \\
\hline & $50.000-100.000$ & - & - & \\
\hline & $100.000-300.000$ & - & - & \\
\hline & $300.000-500.000$ & - & - & \\
\hline & $>=500.000$ & - & - & \\
\hline \multirow[t]{5}{*}{ SD } & $<=50.000$ & 2 & 8 & $37,5 \quad(+)$ \\
\hline & $50.000-100.000$ & 10 & 5 & $31.25(-)$ \\
\hline & $100.000-300.000$ & 4 & 1 & $18,75 \quad(-)$ \\
\hline & $300.000-500.000$ & 1 & 1 & 0 \\
\hline & $>=500.000$ & 1 & 1 & 0 \\
\hline \multirow[t]{5}{*}{ SMP } & $<=50.000$ & 5 & 10 & $31,25 \quad(+)$ \\
\hline & $50.000-100.000$ & 8 & 3 & $31,25 \quad(-)$ \\
\hline & $100.000-300.000$ & 2 & 2 & 0 \\
\hline & $300.000-500.000$ & 1 & 1 & 0 \\
\hline & $>=500.000$ & - & - & \\
\hline \multirow[t]{5}{*}{ SMA } & $<=50.000$ & 0 & 7 & $43,75 \quad(+)$ \\
\hline & $50.000-100.000$ & 2 & 5 & $18,75 \quad(+)$ \\
\hline & $100.000-300.000$ & 2 & 2 & 0 \\
\hline & $300.000-500.000$ & - & - & 0 \\
\hline & $>=500.000$ & 1 & 2 & $6,25 \quad(+)$ \\
\hline SMK & $<=50.000$ & 0 & 3 & $18,75 \quad(+)$ \\
\hline
\end{tabular}




\begin{tabular}{lllll}
\hline $50.000-100.000$ & 2 & 3 & 6,25 & $(+)$ \\
\hline $100.000-300.000$ & 0 & 7 & 43,75 & $(+)$ \\
\hline $300.000-500.000$ & 1 & 2 & 6,25 & $(+)$ \\
\hline$>=500.000$ & 0 & 1 & 6,25 & $(+)$
\end{tabular}

Data hasil penelitian di atas menunjukkan bahwa peningkatan oplah yang terjual untuk produk TK sebesar 87,5 \% sesuai dengan jumlah eksemplar yang diproduksi oleh penerbit. Produksi buku TK masih dalam range $<=50,000$ dari semula yang tidak ada sama sekali. Demikian juga pada produk SMA dan SMK terjadi peningkatan penjualan yang sangat signifikan, yaitu sebesar $43,75 \%$ pada range $<=$ 50.000 , artinya dari tidak menerbitkan sama sekali, sejumlah 43, 75\% akhirnya menerbitkan buku SMA dengan oplah kurang atau sama dengan 50.000 eksemplar. Pada SMK terjadi kenaikan yang signifikan pada range 100.000 -

Faktor-Faktor yang Memengaruhi Perubahan Produksi Buku Teks

\section{Pelajaran}

Perubahan produksi itu terdiri atas kenaikan dan penurunan jumlah judul buku pada jenjang-jenjang pendidikan tertentu. Terjadi
300.000 eksemplar yaitu sebesar $43,75 \%$.

Hal sebaliknya terjadi pada buku SD dan SMP yang mengalami penurunan oplah penjualan dari tiga tahun sebelum kebijakan BSE sampai tiga tahun setelah kebijakan BSE. Penurunan itu sebesar $31,25 \%$ produk SD pada range 50.000 100.000 eksemplar dan 31,25\% produk SMP pada range 100.000 300.000 eksemplar.

Perubahan-perubahan itu disebabkan oleh berbagai faktor, di antaranya faktor internal dari penerbit sendiri dan faktor eksternal, baik dari pemerintah maupun masyarakat. Berikut adalah hasil wawancara mengenai faktor-faktor perubahan tersebut.

penurunan produksi pada buku SD dan SMP. Penurunan produksi pada buku SD dan SMP tersebut disebabkan buku-buku bidang studi pokok untuk jenjang tersebut dijadikan sebagai BSE pada tahun pertama kebijakan mengenai BSE 
(Permendiknas No.2 Tahun 2008). Hal itu terjadi pada penerbit-penerbit skala kecil yang dari perhitungan bisnis mereka tidak menghasilkan keuntungan disebabkan harga BSE yang sangat murah. Namun, untuk penerbit-penerbit skala besar yang memperoleh pemesanan dengan jumlah eksemplar memadai, tetap memproduksi BSE karena tetap bisa mengambil keuntungan meskipun keuntungannya relatif kecil. Selain keuntungan yang relatif kecil, penurunan produksi buku SD dan SMP disebabkan oleh tata niaga buku pelajaran yang diatur dengan Permendiknas No 2 tahun 2008.

Peningkatan produksi buku TK, SMA, dan SMK pada penerbit disebabkan judul-judul buku pada tahun-tahun pertama belum memasukkan semua bidang studi SMA dan SMK. Bidang studi SMA dan SMK yang menjadi program BSE pada tahun pertama adalah Bahasa Inggris dan Matematika. Oleh karena itu, masih terbuka peluang untuk bidang studi yang bisa dijual bebas tanpa harus melalui penilaian terlebih dahulu. Buku-buku itu dijual berdasarkan proyek penilaian sebelum BSE berjalan.
TK, SMA, dan SMK pada tahun 2008 masih dengan leluasa menentukan buku-buku yang digunakan di sekolahnya masingmasing karena belum ada aturan BSE tentang hal itu. Kalaupun ada, masih terbatas untuk mata pelajaran tertentu, seperti Matematika dan Bahasa Inggris. Selain itu, jenjang TK dan SMA belum ada bantuan Dana BOS untuk pembelian buku, maka sekolah masih leluasa menentukan buku mana yang harus dibeli.

\section{Solusi Agar Ketersedian Buku}

Teks Pelajaran Sesuai Kebutuhan

Pada prinsipnya, masyarakat dalam hal ini sekolah, orang tua, penerbit, dan percetakan menerima kebijakan BSE. Namun, kebijakan itu perlu dikaji lagi agar lebih sesuai dengan kondisi masyarakat. Misalnya, penerapan kebijakan BSE yang mengharuskan sekolah membeli buku tidak langsung ke penerbit, mesti dipertimbangkan kemudahan akses distribusinya. Oleh karena itu, penentuan HET juga perlu diperhitungkan biaya distribusinya. Tanpa memperhitungkan biaya distribusi, 
maka sangat sulit bagi penerbit untuk menerbitkan buku sekolah (BSE) karena tidak akan memperoleh keuntungan sama sekali.

Perlu diatur tata niaga buku sekolah agar menguntungkan semua pihak sehingga ketersediaan buku sekolah tetap terjaga, mengingat buku teks merupakan salah satu sumber belajar yang penting di sekolah. Karut marut bisnis buku sekolah diperparah oleh oknumoknum yang memanfaatkan untuk kepentingan-kepentingan pribadi, seperti permainan rabat yang tentu merugikan berbagai pihak. Oleh karena itu, perlu dipikirkan sebuah kebijakan agar permainan rabat tersebut tidak terjadi lagi.

\section{Usulan Kebijakan Pemerintah}

\section{Mengenai Perbukuan Nasional}

Perbukuan nasional melibatkan berbagai pihak yang terkait, seperti penulis, penerbit, percetakan, sekolah, orang tua, dan penerbit. Kebijakan pemerintah mengenai perbukuan nasional harus mengakomodir semua kepentingan berbagai pihak yang terkait pada perbukuan nasional tersebut. Kebijakan BSE yang semata-mata ingin mengejar harga murah agar masyarakat memperoleh buku dengan mudah rupanya tidak serta merta terpenuhi. Hal itu masih harus mempertimbangkan siapa yang akan mencetaknya, siapa yang akan menerbitkan, dan siapa yang akan mendistribusikannya.

Kebijakan BSE yang juga menentukan kualitas buku ternyata tidak serta merta juga memenuhi kualitas yang diharapkan. Meskipun masih perlu penelitian lebih lanjut, namun keluhan dari beberapa kalangan guru perlu juga diperhatikan, yaitu mengenai kualitas isi buku yang masih kurang memenuhi standard kompetensi yang diharapkan. Oleh karena itu, proses penilaian buku perlu diperketat lagi agar tidak terjadi praktek-praktek penyimpangan oleh oknum-oknum yang tidak bertanggung jawab.

Mengenai penilaian buku tersebut, perlu ada komitmen juga dari pemerintah untuk tetap mengup load buku-buku yang sudah lulus penilaian. Hal itu selain sebagai bentuk penghargaan kepada penulis dan penerbit yang bukunya telah lulus, juga lebih memperbanyak pilihan bagi pihak-pihak yang akan 
mencetak BSE. Pembelian hak cipta oleh pemerintah perlu diatur kembali mekanismenya agar tetap menggairahkan para penulis buku untuk menjual hak ciptanya. Harga hak cipta yang menurun akibat sistem tender menyebabkan beberapa oknum membanting harga sedemikian rupa yang penting bukunya terbeli. Tentu saja hal itu merugikan para penulis buku yang ingin tetap bertahan dengan kualitas buku yang memadai.

Proses pengadaaan buku sekolah perlu mendapat perhatian dari pemerintah, terutama mengenai ketersediaan dana agar tepat waktu. Mungkin juga perlu dipikirkan sebuah mekanisme baru mengenai penyediaan buku teks pelajaran ini bagi peserta didik. Tentu saja kebijakan itu tidak hanya menguntungkan pihak tertentu tetapi menguntungkan berbagai pihak, baik sekolah, orang tua, penerbit, percetakan, agen, distribusi, dan toko buku. Hal itu perlu karena bila kita berbicara untuk kepentingan masyarakat, maka masyarakat adalah semua yang terlibat pada kegiatan kehidupan dan penghidupan seharihari di negara ini.

\section{PENUTUP}

Kebijakan BSE memengaruhi produksi buku teks pelajaran oleh penerbit buku sekolah. Persentase perubahan itu meliputi produksi buku TK, SD, SMP, SMA, dan SMK. Produksi buku TK mengalami kenaikan sebesar 87,5\% pada kisaran $<=50.000$ eksemplar. Buku SMA mengalami kenaikan yang signifikan sebesar $43,75 \%$ pada kisaran <= 50.000 eksemplar, sedangkan buku SMK mengalami kenaikan sebesar $43,75 \%$ pada kisaran 100.000 300.000 eksemplar. Sebaliknya, terjadi penurunan produksi buku SD dan SMP sebesar 31,25\% pada kisaran 50.000 - 100.000 eksemplar.

Beberapa faktor penyebab perubahan itu antara lain:

a. Buku SD dan SMP yang dijadikan sebagai BSE relatif lebih lengkap, sehingga penerbit menurunkan produksinya karena BSE tidak mendatangkan keuntungan yang signifikan.

b. Implementasi kebijakan BSE yang masih belum sesuai dengan harapan karena adanya penyimpangan oleh oknum- 
oknum untuk memperoleh keuntungan pribadi.

c. Mekanisme pengadaan buku sekolah yang sering terhambat oleh ketidaklancaran pencairan dana dari pemerintah. Naskah BSE rata-rata belum siap untuk diproduksi karena masih RGB dan kamera Ready Copy (CMYK).

Solusi yang ditawarkan agar ketersediaan buku teks pelajaran sesuai dengan kebutuhan adalah (1) perlu memperhitungkan biaya distribusi pada perhitungan HET BSE dan (2) perlu diatur kembali tata niaga buku teks pelajaran agar tidak terjadi permainan rabat yang dapat merugikan berbagai pihak. Usulan kebijakan pemerintah mengenai perbukuan nasional adalah kebijakan yang dapat mengakomodir kepentingan masyarakat. Dalam hal ini masyarakat perbukuan nasional, khususnya buku teks pelajaran adalah sekolah, orang tua, penulis, penerbit, dan percetakan. Perlu dibuat kebijakan yang dapat menguntungkan semua pihak, terutama yang lebih penting lagi adalah kemudahan memperoleh buku bagi peserta didik karena buku merupakan salah satu sumber belajar yang penting.

\section{DAFTAR RUJUKAN}

Agung, I, Gusti Ngurah. 2001, Statistik Analisis, Hubungan Kasual berdasarkan Data Kategorik. Raja grafindo perkasa. Jakarta

Damodar, Gujarati N. 2003, "Basic Economic", Third Edition, Singapore: Mc Graw Hill, Corporation

Fernandez, Daniel. 2011. Survei Penggunaan Buku Teks Dari Penerbit Swasta Non- BSE. Universitas Muhammadiyah Prof. DR. Hamka

Furqon, 2004, Statistika Terapan Untuk Penelitian, Cetakan kelima, edisi revisi, Alpha Beta $\mathrm{CV}$, Bandung.

Harahap,Mula, (2010), Kemelut Industri Penerbitan Buku Sekolah, http://www.mulaharahap.word press.com. Diakses 20 Januari 2011.

http://id.wikipedia.org/wiki/Buku_Se kolah_Elektronik

http://apakabarpsbg.wordpress.com/2 008/07/03/buku-sekolahelektronik/\#comment-442

http://abdul1manaf2marpaung.wordp ress.com/2009/11/21/menguak- 
tabir-kebijakan-buku-sekolah/

diakses 6 Mei 2011

http://sawali.info/2008/06/27/bukusekolah-elektronik-terobosanyang-jitu-dan-visioner/

http://bse.depdiknas.go.id

-------- Nasib Penerbit dan Penulis Buku Pasca BSE http://sawali.info

Kotler, Philip danKevin Lane Keller, 2007: Marketing Management, Pearson

Prentice Hall, New Jerse

Pakar, Dani.2005, Bagaimana dan Mengapa Penerbitan Buku, IKAPI DKI. Jakarta
Slovin, 1992, dalam Moch. Idochi Anwar, Skala Pengukuran Variabel-variabel Penelitian, Alfabeta, Bandung, 2002

Stanton J, William.1991. Prinsip Pemasaran. Alih bahasa Yohannes Lamarto, Penerbit Erlangga

Trim, Bambang. (2009), Catatan dari REX-IKAPI Editor's: Kita tidak kalah, http://www.kompasiana.com Diakses 20 Januari 2011.

Buku Sekolah Pasca BSE http://sawali,info 2011/08/20 